\title{
Proposed indicators for socio taqwa index indicator in Kelantan state Government
}

\author{
Nur Fatinah Binti Mohd Azhar ${ }^{1}$, Mohd Nuri Al-Amin Endut ${ }^{2}$, and Muhammad Ridhuan Tony Lim Abdullah ${ }^{3}$ \\ ${ }_{1,2,3}$ Department of Management and Humanities, Universiti Teknologi PETRONAS, 32610 Bandar Seri Iskandar, Perak, \\ Malaysia
}

\begin{abstract}
The Kelantan state government has used the Developing with Islam policy to carry out its administration since 1990 in the state of kelantan. Various programs and changes have been implemented in 5 aspect which is in administration, shariah, economy, education and sociology. Since 1990, the Developing with Islam policy still ongoing. However, no comprehensive study has been conducted on all aspects of the Developing with Islam policy. Therefore, this study was conducted to produce appropriate indicators that will be used to see the effectiveness of the Developing with Islam policy in Kelantan. In this study paper will explain where these indicators are come from. By having this indicators, Kelantan state government can create an index and at the same time can evaluate the achievement of the policy since the policy was implemented. The result can help Kelantan state government to make improvement from time to time and become as a good example of Islamic state in Malaysia.
\end{abstract}

Keywords: Developing with Islam, Indicators, changes

\section{Introduction}

Kelantan is one of the states that have an earliest history of Islam in Malaysia. The Kelantan State was well known as Islamic expansion since 12 century (Yusuff \& Nik Abdullah, 2007). At that time, Kelantan was known by a number of names and nick names. About a thousand years ago, Kelantan was known as "Medang Kemulaan" which means the initial battlefield (Nakula,1980). This name change to "Medang Gana"since from the $1^{\text {st }}$ century to $5^{\text {th }}$ century. Then it changed to Kelantan or "Tanah Kala". That is a little bit about the history of Kelantan.

But what is even more interesting is that the Kelantan state government is led by PAS (the Islamic Party of Malaysia) mostly. In 1990, PAS won the 8th General Election in Kelantan using the slogan of 'Developing with Islam'. After successfully won the election on October 21, 1990, PAS adopted the slogan of 'Building Together Islam' which was used during the 8th general election as the basis of government in Kelantan. The Developing with Islam Policy was formally written in 2005 and passed to the state government in 2006 . The policy is also a reference in the framework of state development programs and projects.

The vision of this policy is to make the state of Kelantan a state that practices Islam in daily life. Kelantan State Government mission is to implement the state and society development based on Islamic teachings which is shared through human development and strategic planning (Wan Nik Wan Yussof, 2013).

Based on the Developing with Islam Policies, many new programs and regulations have been proposed and implemented. These Kelantan state government efforts show that they are serious about realizing their vision and mission.

\section{Problem Statement}

In line with the Developing with Islam Policy as stated in the introduction, the Kelantan State Government implemented the development and administration of the State government in five major areas. These areas are shariah, administration, education, economics and sociology.

From a shariah perspective, the Kelantan state government has implemented a campaign of covering aurah and enforce it through the authority of the Municipal Council and hold weekly religious lectures under the supervision of the Halaqat Unit. In the field of administration, the Kelantan state government has set up the administration of the state government and all state government agencies with three important values namely 'ubudiyyah, masuliyyah and itqan.

Ubudiyyah refers to man's position as a servant of Allah S.W.T created to worship Him. Masuliyyah also means to assume responsibility while itqan refers to the quality of work that emphasizes perseverance, commitment and determination. The application of these three values to all civil servants in state government agencies is aimed at preventing abuse and neglect in the administration (Nik Abdul Aziz Nik Mat, 1995). 
In education, the Kelantan state government's effort is to put a responsibility on state government agency to focus on managing educational affairs. The agency is the Kelantan Islamic Foundation (YIK) which aims to produce Muslims who are believers, virtuous, knowledgeable, righteous and worthy of service to build families, communities, states and communities.

In the economic aspect, the Kelantan state government has put five basic elements as the aim of the state's economic development. The first is, achieving a balanced development, second, developing productive human resources, third, optimizing production and productivity, fourth, improving the standard of living and quality of life of the people and prosperity and well-being of the people.

In sociology, the approach and method used for the development of the State government is a method known as al-amr bi-l-ma'rüf wa-n-nahy 'ani-l-munkar; which may be translated as commanding what is just and forbidding what is evil. There are three steps taken by the State government to enhance, protect and prevent (Mohamed Anwar Omar Din, 2011). Among them are to nourish, sustain, and promote all existing practices in Kelantan society that have good and positive values in Islam and prevent practices that are clearly contrary to Islam and universal human values.

Based on all the efforts made by the Kelantan State government, it seems that the Kelantan State Government is very serious in pursuing the Developing with Islam Policy. In the efforts of the Kelantan State Government to implement the Developing with Islam Policy, several studies have been conducted to see its effectiveness.

For example, a study on the practice of Islamic Economy in the State of Kelantan (Martyrs, Adib 2013). The study was conducted to look at the economic development that took place in Kelantan after 1990. In addition, this study was conducted to assess poverty and to identify policies and programs implemented in addressing the problem of poverty.

In addition, there is a study entitled Implementation of the Mas'uliyyah Concept and Trust in the Public Administration of the Cleanliness of Corruption-Studies at the Municipal Council of Kota Bharu-Islamic City (Nurafilah Musa). Various policies and plans at the national level have been formulated and were implemented. Moreover, at the state level of Kelantan itself, the UMI concept (Ubudiyyah, Masuliyyah and Itqan) is adopted as the basis of the state's civil service. That is why the study was conducted to explain the importance of the Masuliyyah concept towards creating a clean administration.

Another other research is regarding Establishing an Islamic State: Ideals and Realities in the state of Kelantan Malaysia (Syukri Salleh, 1999). This paper observes an experience in establishing an Islamic State in the state of Kelantan, Malaysia, undertaken by the Malaysian Pan Islamic Party (PAS) led government.

Although studies on programs and regulations have been conducted to see the effectiveness of these programs, they are not comprehensive. The studies that are carried out mostly focus on just one aspect, such as focusing only on economics, administration and others. This makes the Kelantan State government unable to fully know the impact of the Developing with Islam Policy that has been implemented. The purpose of this study is to produce indicators that $\mathrm{w}$ be used to evaluate the effectiveness of the Developing with Islam Policy in the State of Kelantan.

\section{Literature Review}

Based on M. Kamil et al. (2011) andN. M. Kamil et al. (2015), taqwa consist of two main dimensions of Islamic Spirituality (IS) and Islamic Social Responsibility (ISR). In other words, as IS tends to strengthen the bond between man and Allah, ISR tends to strengthen the bond of society, thus between man and man, man and nature, as well as man and the entire universe. The comprehensiveness of the taqwa construct is thus, envisioned to be holistic, engulfing most present concepts that are captured in western literature, such as corporate social responsibility.

Other than that (Maham) in his research also stated that taqwa has two distinct components: Islamic Spirituality (IS) and Islamic Social Responsibility (ISR). At an operational level IS refers to those activities Muslim engage in both in the workplace and elsewhere in a manner that is consistent with the teachings of Islam while Islamic Social Responsibilities refers to those values Muslims engage in within organizations that result in mutual respect, coexistence, and the development of the person, the organization and mankind in a manner that reflects remembrance of Allah and seeking His approval (Kamil, 2012). 
Table 1: Summary of components of taqwa based on the characteristic of the motaqeen (adopted from Kamil (2012)

\begin{tabular}{|l|l|}
\hline \multicolumn{2}{|c|}{ COMPONENT OF TAQWA } \\
$\begin{array}{c}\text { ISLAMIC SPIRITUALITY } \\
\text { (bond between man and Allah) }\end{array}$ & $\begin{array}{c}\text { ISLAMIC SOCIAL RESPONSIBILITY } \\
\text { (the bond of society, between man and man, } \\
\text { man and nature, as well as man and entire } \\
\text { universe) }\end{array}$ \\
\hline Belief & Patience \\
\hline Rituals (Ibadah) & Emotional Control \\
\hline $\begin{array}{c}\text { Declaring faith in Allah (kalimah } \\
\text { syahadah) }\end{array}$ & Forgiveness \\
\hline Prayer & Justice \\
\hline Fasting & Integrity \\
\hline Zakat & Fulfilment of the covenant \\
\hline Hajj / Pilgrimage & Truthfulness \\
\hline Repentance & \\
\hline Seeking Allah forgiveness & \\
\hline Remembrance of Allah & \\
\hline
\end{tabular}

So, in this Socio Taqwa Index Indicator, in order to know the level of practices of taqwa in the society, Islamic social responsibility is the most suitable indicator to use because Islamic Social Responsibilities is the connection between man and man, man and nature, as well as man and entire universe. Islamic Social Responsibility is more compatible with the society rather than Islamic Spirituality.

In addition to this, the Prophet (p.b.u.h) has also mentioned in a hadith saying "a believer (someone with high Islamic Spirituality) may steal, may fornicate, and may commit sins, but the believer will never lie". Lying, as mentioned in this hadith is negative function captured in the "Truthfulness" sub-construct of Islamic Social Responsibility. This leads us to the believe that, a person who possesses high Islamic Spirituality, may not necessarily exhibit OCBIP if she/he does not possess good manners (generous behavior).

Another point worth mentioning in support of the Islamic Spirituality statistical insignificant is found in the works of Prominent Muslim scholars such as Imam Ibn Taimiyah. In Ibn Taymiyah's (2006) works in the book (Al-Imam Al-Wsat), he mentioned that faith (Sulaiman et al.) (a component of IS) is not complete by mere belief in the heart and utterance by the tongue. It has to be completed by action. This thus, suggests increasing Islamic Social Responsibility by putting faith into practice. This is also supported by Raba (2001) who mentioned that the effect of valid faith leads human beings to performing good deeds, such as being heedful, truthful, disciplined and sincere. It can be noted that truthfulness, sincerity (integrity, in this study) are all ISR components but not IS. So, most of the aforementioned meanings of taqwa give us a picture that in order to know whether someone possesses taqwa is by refering to his or her action and practice.

According to the literature review, the components of taqwa are divided into two sections namely Islamic spirituality and Islamic Social Responsibilities. But Islamic Social Responsibilities are the best option in assessing the level of piety because it is between humans and humans, humans with nature and others. Similarly, in this study which indicator will be used to evaluate the level of practices, the question that arises is where can this indicator befound.

Because this study involved the State of Kelantan, the researcher has used the Islamic Development Policy as a guide to produce indicators that will be used for this study. The Kelantan State Government has actually used the Islamic Development Policy as a guiding principle for its people. In the context of developing Islam together, its aspects are from the administrative, educational, economic, shariah and socio- cultural fronts.

For this study, the researcher will analyse the whole aspect using 7 indicators. These include administration, education, economics, Islamic practice, Islamic culture, cooperation and social life. These seven indicators will be 
presented to the expert panel to assess whether these indicators can be used to assess the level of piety among the Kelantan society..

\section{Findings}

According to the literature review, the components of taqwa (piety) are divided into two sections namely Islamic Spirituality and Islamic Social Responsibilities. But Islamic Social Responsibilities are the best option in assessing the level of piety because it is between humans and humans, humans with nature and others. Similarly, in this study, indicators that are based on Islamic Social Responsibility will be produced.

Because this study is to produce indicators to know the level of implementation of Developing with Islam Policy, the indicators to be used are also based on the 5 aspects that the Kelantan State Government has made in the Developing with Islam Policy. The 5 aspects are administrative, educational, economic, shariah and socio-cultural. Therefore, this study will use 7 indicators based on the 5 aspect mention in the Developing with Islam. The seven indicators are Islamic practices, Islamic culture, education, administration, economics, cooperation and social. These seven indicators will be presented to the expert panel to assess whether these indicators are suitable to assess the level of piety among Kelantan society or not. Based on the shariah concept in the Developing with Islam Policy, on sharia, the researcher has divided the shariah aspects into two parts, namely in Islamic practices and Islamic culture.

\subsection{IslamicPractice}

Islamic practices is among the indicators proposed. Islamic practices in this study meant the practice of worship among the people of Kelantan. This indicators is to know to what extent the people of Kelantan carry out religious orders and the value of this indicator is from the point of view of the worshippers in the mosques in Kelantan; whether the people attend and enliven the mosque by attending religious activities such as jemaah prayers, attending lectures and so on. In the past, the mosque used to be an administrative center, where religious scholars gathered.

The mosque is a symbol of Islam and a center for Islamic teachings and a gathering place for uniting Muslims. This is because, in the mosque, Muslims can worship more and more securely, perform jemaah prayers, gain knowledge and advice on their goodness and well-being in the world and the hereafter (Alim, 2010). Therefore, Allah greatly elevates those who visit the mosque. As the word of God says in the surah at taubah verse 18:

The mosque of Allah are only to be maintained by those who believe in Allah and the Last Day and establish prayer and give zakah and do not fear except Allah, for it is expected that those will be of the (rightly) guided.

The next aspect to consider is the religious practices. For example, fasting, pilgrimage, sacrifice, aqiqah and so on. Researchers evaluate whether the people in Kelantan are concerned about the religious practices in their daily lives or not. Generally, religious practices become indicators because religious practices are capable of shaping Muslim personalities. For example, fasting itself can shape a devout and faithful Muslim.

\subsection{Islamic Culture}

The Islamic culture indicator in this research is to know to what extent the Islamic culture can be sustained or improved in Kelantan during the existence of the Developing with Islam Policy in Kelantan. In this indicator, four sub indicators are used. The first is from the cultural point of view of Islamic morality. In this regard, the social and moral angles are evaluated to determine the level of practice of piety in society. Judgments are made on the basis of a person's behavior, such as being respectful of one another, speaking softly, politely and others.

Besides that, another aspect to examine from the cultural point of view is Islamic art, which is to investigate the Kelantan state's interest in Islamic art. For example, from the architectural point of view in Kelantan, the involvement of aspects of Javanese language, khat art, painting and others. The next aspect to consider is the culture of healthy living practices. From this point of view, the researcher evaluate Kelantanese dietary practices and sports activities. Nutrition is one of the factors that influence the worship practice. Islam values good nutrition for its people because their lives on earth are accompanied by their role and duties as a caliph.

By maintaining good health, a Muslim man is able to perform all his duties, work, seek knowledge and others. The disruption of health affects the quality of worship and the value of Muslim piety in the presence of Allah SWT while the formation of good character begins with perfect knowledge, faith and charity to Allah SWT. Value of faith and piety with the good practices that he practices will be compromised if the body is unwell, and furthermore when the food and drink taken are non-halal. Allah also mentions in surah Al-A'raf verse 31:

"Eat and drink and do not be excessive" 
The fourth factor is the cultivation of a sustainable environment which means assessing the level of hygiene in Kelantan. Muslims are encouraged to keep the body clean. Not only that, the cleanliness of the environment is also emphasized because it represents a Muslim personality. Cleanliness should also be taken care of physically and internally. Physical means the external cleanliness whereas inner purity means inner qualities which please God. By being physically and mentally clean, worship can be performed well and can reach the level of piety. Therefore, Islamic culture has been selected as one of the indicators to assess the level of piety among the people of Kelantan.

\subsection{Economy}

In the context of Developing with Islam Policy in the State of Kelantan, the scope of the economy was also enhanced. But what are the changes that has been made? Therefore, economic indicators are also created. In the economy, there are three sub indicators to be used: the first is from generation of income and the valuation is based on how they generate daily income. Second, infaq, charity and waqaf aspect. Do they live in the culture of giving each other or not. The third sub indicator is in terms of demand and use of Islamic financial products

In Al-Quran, Allah really encourages his servants to obey the guidelines set by Him. For example, Allah has decreed that the prohibition of riba (usury) in business matters. This at the same time prevents society from being oppressed. Other than that, there are other guidelines like authorized batter system, pre-order system, way of buying and more. If the people of Kelantan are able to apply what God requires by disregarding the benefits then the people of Kelantan are a people of piety.

The fact is, humans are capable of doing anything and ignoring what is illegal. But for Muslims who have strong faith values, they will stand firm in the stance God has set for Muslims. Therefore, this indicator was selected to measure to what extent, economic aspect has been changed since Kelantan state government applies the Developing with Islam Policy.

\subsection{Education}

In addition, in the Developing with Islam Policy there is development in the scope of education. Educational indicators are then created to assess the effectiveness of the educational system. In education indicators there are two sub indicators used, lifelong learning culture, which assesses the level of Kelantan society's interest in knowledge. Whether the passion for knowledge is born out of life or just in the middle of the road. As the Arabic proverb says, 'gain knowledge from the cradle to the grave'. This saying shows that knowledge is not just in school or university, but that knowledge is one that gives one the last breath in the world.

The next thing to consider is the tendency to choose the Islamic education. In Kelantan, there are many religious-based educational institutions for example, Sultan Ismail Petra Islamic College, Pondok schools, tahfiz centers, tahfiz science schools and so on. However, with this indicator, the effectiveness and application of all these educational institutions can be evaluated. The existence of this religious-based education center is in line with the Kelantan state education curriculum which features divinity and curriculum and co-curriculum.

It encompasses all aspects of [the faith] as well as knowledge, skills, norms, values, and cultural elements. It is not only a written curriculum but also a hidden curriculum that will meet the spiritual, physical, spiritual and emotional needs. Its contents are a mixture of naqli and aqli knowledge (Yusoff, 2017). Therefore, this educational indicator is used to know to what extent the Developing with Islam Policy gives impact towards the education system.

\subsection{Cooperation}

The indicator of cooperation means a spirit of helpfulness in the community. The two sub indicators evaluated are the practice of helping people in the community whether they are cooperative and help each other (in terms of material, energy and time). The second sub indicator is the response and participation of the people in the welfare program. 
Based on surah Al-Maidah verse 2.

"O you who believe! Violate not the sanctity of the symbols of Allah, nor of the sacred month, nor of the animals brought for sacrifice, nor the garlands that mark out such animals, nor the people resorting to the sacred house, seeking of the bounty and good pleasure of their Lord. But when you are clear of the sacred precincts and of pilgrim garb, you may hunt and let not the hatred of some people in (once) shutting you out of the Sacred Mosque lead you to transgression (and hostility on your part). Help you one another in righteousness and piety, but help you not one another in sin and rancor: fear Allah: for Allah is strict in punishment.

In this verse, God encourages human to help one another and achieve taqwa. The assistance that Allah mentions in this verse is assistance in goodness. For example, helping the Muslim community in need. God strongly forbids people to help commit sin and hostility. For examples help distribute drugs, steal, etc. Therefore, this indicator was selected to measure the level of devotion among the people of Kelantan.

\subsection{Administration}

The administrative aspect is also one of the areas for improvement in the Developing with Islam Policy in the State of Kelantan. Therefore, in this study there are administrative indicators used to measure the success of Kelantan government proposed changes in the Developing with Islam Policy. So, in this indicator, the sub indicator used is the people's sensitivity to administrative integrity. For example, by looking at the level of society that is practiced by transparency of administration or society receives the administrative system as it is.

The next sub-indicator is the maturity of the people in the selection of leadership. In this regard, assessments are made based on the people's election to the election of leaders. The level of society's tendency is to select leaders who can only promise or choose leaders who can lead a truly Islamic state. Therefore, this indicator was chosen to measure the level of practice of the Kelantan state because the administration plays an important role in carrying $\begin{array}{lllll}\text { out activities } & \text { in } & \text { Administration } & \text { is the main }\end{array}$ pillar.

\subsection{Society}

In the Developing with Islam Policy there are aspects of sociocultural that are being made. So, in this aspect, there are many programs has been made but there is no specific research which evaluates the successfulness of those programs. Because of that, this study created society indicator to look at the implementation of the socio-cultural in the Developing with Islam Policy at Kelantan State Government.

In this research, among the aspects considered are social practices, social security (crime rates) and family culture of harmony and caring. Based on surah Ali-Imran verse 102-104, God explains how to build a society and achieve high level of taqwa in society. God had mentioned the tips in this verse is to safeguard the principle of Islam sincerely until no one in the society died in disbelief. In addition, the relations between the societies are also closely related. In addition, in order to achieve taqwa, the amar makruf nahi mungkar in the society level must be maintained.

Every one of the muslims, is demanded by Allah to attain the devotion because Allah tells us a great deal about the state of heaven that will be achieved by the Muslims who are really striving to achieve the devotion Therefore, this indicator was chosen to serve as an indicator to determine the level of devotion in Kelantan.

\section{Conclusion}

It is hoped that the expert panel will see the relevance of the proposed indicators. The proposed indicator must have its own weaknesses and will change over time. Hoping that with this effort, it will help the Kelantan State government to develop an index to measure the effectiveness of the Developing with Islam Policy in the State of Kelantan in the future since the policy was implemented. The result can help Kelantan state government to make improvement from time to time and become a good example of Islamic state in Malaysia. 


\section{References}

Ahmad M. Raba. (2001). Major Personalities in The Qur'an. Kuala Lumpur: A.S. Noordeen

Ibn al-Taymiyyah, 1988, Taqiuddin Ibn Ahmad. (1988). al-Siyasah al-Syar`iyyah fi Islah al-Ra`i wa alRa`iyyah. Beirut: Dar al-Afaq al-Jadidah.

Kamil, M., Ali Hussain, A.-K., \& Sulaiman, M. B. (2011). The components of spirituality in the business organizational context: The case of Malaysia.

Kamil, N. M., Sulaimam, M., Selladurai, S., \& Khalid, N. J. J. K., Malaysian Journal of Communication. (2015). The impact of spirituality and social responsibility on organizational citizenship behaviour from the Islamic perspective: Empirical investigation of Malaysian businesses. 31(1).

Mohamed Anwar Omar Din, 2011, Pelancongan Budaya di Malaysia: Membina Konsepnya (Cultural Tourism in Malaysia: Con- guring its Concept),Jurnal Melayu (6)2011:1-11

Muhammad Syukri Salleh, 1999, Establishing an Islamic State: Ideals and Realities in the state of Kelantan, Malaysia.Southeast Asean Studies. Vol. 37, No. 2, Sept 1999

Nakula, A., 1980. Sejarah Kelantan: Beberapa Lintasan Kota Bharu: Kementerian Kebudayaan, Belia dan Sukan. Nik Abdul Aziz Nik Mat, 1995, Kelantan, agenda baru untuk umat Islam, Rangkaian Minda Pub.wa

Wan Ahmad, W.Y., 1985. The Early Development of Islamic education in Kelantan, $\quad$ in ISLAMIKA, Kuala Lumpur pp:111.

Wan Nik Wan Yussof. (2011). Perspektif Tok Guru. Kota Bharu: Pusat Kajian Strategik Kerajaan Negeri Kelantan. 